\title{
The Location of Nisin in the Producer Organism, Streptococcus lactis
}

\author{
By R. J. WHITE* AND A. HURST $\dagger$ \\ Chemical Microbiology Section, Unilever Research Laboratory, \\ Sharnbrook, Bedford
}

(Accepted for publication 28 March 1968)

SUMMARY

Streptococcus lactis organisms grown in a glucose-containing medium $\mathrm{pH}$ maintained at $\mathrm{pH} 6.8$ (neutral cocci) contained three- to seven-fold more nisin/unit dry weight than cocci grown in the same medium without $\mathrm{pH}$ control (acid cocci, terminal $\mathrm{pH}_{4} \cdot 2$ ). After chemical fractionation of acid cocci $57 \%$ of the nisin was found in the fraction soluble in aqueous ethanol and $36 \%$ in a trypsin-insoluble residue. After fractionation of broken cocci (acid and neutral) by differential centrifugation up to $60 \%$ of the nisin was found in the $10,000 \mathrm{~g}$ sediment (walls). Nisin was also present in the $30,000 \mathrm{~g}$ sediment (membranes) and the $100,000 \mathrm{~g}$ sediment (ribosomes). The major difference between acid and neutral cocci was in the $100,000 \mathrm{~g}$ supernatant fluid (cell sap); cell sap from neutral cocci was $0.28 \%$ nisin whereas that from acid cocci was $0.04 \%$ nisin. Analysis of the cell wall indicated that it was composed of mucopeptide and polysaccharide. Teichoic acid could not be extracted. The polysaccharide was soluble in hot formamide and accounted for one-third of the dry weight of the wall; it contained rhamnose, galactose, glucose, glucosamine in the molar ratio of $5: \mathrm{I}: \mathrm{I}: \mathrm{I}$. Cell walls contributed $31 \%$ to the dry weight of acid cocci and $42 \%$ to the dry weight of neutral cocci.

\section{INTRODUCTION}

Many suggestions now exist in the literature that basic polypeptide antibiotics play a role in the bacterial differentiation which occurs at the time of sporulation (e.g. Schaeffer et al. 1963, Halvorson, 1965). Recently, further evidence supporting this notion has been obtained with Bacillus polymixa (Paulus, 1967). The role of basic proteins in the more overt differentiation processes of eukarytotic systems has been under discussion for several years (de Reuck \& Knight, I966). Recently, for example, Butler \& Chipperfield (1967) showed that the inhibition of RNA polymerase by histones was a genuine effect and not an artefact due to decreased solubility. Certain strains of Streptococcus lactis produce an antibiotic called nisin, which is active against several Gram-positive bacteria (Mattick \& Hirsch, 1947). This antibiotic is a small basic protein, and Hurst (1967) suggested that it may play a regulatory role in the producer organism connected with initiation and halting of growth. Thus the length of lag-phase of growth is directly related to the nisin content of the organism (Hurst \& Dring, 1967). Recently Gross \& Morell (1967) proposed that the antibiotic

* Present address: Department of Biochemistry, South Parks Road, University of Oxford.

$\dagger$ Present address: Department of National Health and Welfare, Tunney's Pasture, Ottawa, Canada. 
effect of nisin depends on interception of sulphydryl groups of metabolically important molecules such as co-enzyme A. Cheeseman \& Berridge (1959) proposed that the molecular weight of nisin is 7,000, however Gross \& Morell (1967) reported a value of 3,500; our own work (Ingram, Tombs \& Hurst, 1967) has confirmed the original estimate of 7,000 . Unlike other polypeptide antibiotics so far studied in detail, nisin appears to be synthesized ribosomally (Hurst, I966a). In view of the possible function of nisin as a regulator in the producer organism we attempted in the present work to locate it within the cell by using chemical and physical procedures of cell fractionation.

\section{METHODS}

Organisms, media and culture conditions have already been described (Hurst, 1966 $a, b$ )

Nisin was estimated by bioassay against Streptococcus cremoris strain IP 5 using the standard of Hurst (I966a). Nisin bound to bacteria (cell nisin) was extracted and assayed after washing the cocci in fresh medium. Cell fractions for bioassay were adjusted with $10 \mathrm{~N}-\mathrm{HCl}$ to give a final concentration of $0.05 \mathrm{~N}-\mathrm{HCl}$. $\mathrm{HCl}$ was not added to samples containing trichloroacetic acid (TCA). Before assay, samples were heated in a boiling water-bath for 5 min., centrifuged and the clear supernatant fluid used for assay.

Chemical fractionation of bacteria was as described by Park \& Hancock (1960) except that the time of digestion with trypsin was increased to $3 \mathrm{hr}$. Briefly this method consisted of suspending a pellet containing $3 \mathrm{mg}$. dry wt in $3 \mathrm{ml}$. cold $5 \% \mathrm{TCA}$. The supernatant after centrifuging contained the low molecular weight TCA soluble substances. The residue was extracted at room temperature with $75 \%$ aqueous ethanol; the supernatant after centrifuging contained much of the lipid and other alcohol soluble cellular material. The residue was extracted with $5 \%$ TCA at $90^{\circ}$ for $6 \mathrm{~min}$. to dissolve nucleic acid and the residue was trypsin digested for $3 \mathrm{hr}$ at $37^{\circ}$ (I $\mathrm{mg}$. crystalline trypsin/ml. of $0.05 \mathrm{M}-\left(\mathrm{NH}_{4}\right) \mathrm{HCO}_{3}$ containing $\left.0.005 \mathrm{~N}-\mathrm{NH}_{4} \mathrm{OH}\right)$. The final residue after trypsin extraction was resuspended in $3 \mathrm{ml}$. of $0.05 \mathrm{~N}-\mathrm{HCl}$, placed in a boiling water-bath for $5 \mathrm{~min}$., centrifuged and the clear supernatant assayed.

Physical fractionation of bacteria. Washed suspensions of Streptococcus lactis strain in water were disrupted in a French pressure cell (American Instrument Co. Inc., Silver Spring, Md., U.S.A.) or a Braun homogenizer (Shandon Instrument Co., London), any intact cocci which survived being removed by twice centrifuging at $3000 \mathrm{~g}$ for Io min., and discarding the sediment. The broken cocci were separated into four fractions by differential centrifugation: (i) $10,000 \mathrm{~g}$ sediment; (ii) $30,000 \mathrm{~g}$ sediment; (iii) I00,000 $g$ sediment: (iv) I00,000 $g$ supernatant fluid.

Cell walls (10,000 $g$ sediment) were prepared by centrifuging broken cocci at I0,000 $g$ for Io min., washing the sediment twice with $\mathrm{M}-\mathrm{NaCl}$, and twice with dis tilled water. Cell walls were then digested with trypsin (100 $\mu \mathrm{g} . / \mathrm{ml}$. at $37^{\circ}$ in $0.0 \mathrm{I} \mathrm{M-}$ sodium phosphate buffer $\mathrm{pH} 7 \cdot 0$ for $3 \mathrm{hr}$ ), after digestion the walls were washed and resuspended in distilled water.

Membranes (30,000 $g$ sediment) were prepared by centrifuging the $10,000 \mathrm{~g}$ supernatant fluid at $30,000 \mathrm{~g}$ for $30 \mathrm{~min}$. and washing the sediment twice with $\mathrm{M}-\mathrm{NaCl}$ and twice with water. Although the $30,000 \mathrm{~g}$ sediment was designated membranes it undoubtedly contained other material as well, and was frequently contaminated with cell walls (as judged by amino sugar content); attempts to prepare membranes from spheroplasts of Streptococcus lactis were not successful. 
Ribosomes ( $100,000 \mathrm{~g}$ sediment) were sedimented from the $30,000 \mathrm{~g}$ supernatant fluid by centrifuging at $100,000 \mathrm{~g}$ for $3 \mathrm{hr}$ then washed and resuspended in the buffer described by Munro, Jackson \& Korner (I964).

When appropriate, the nature of the fractions obtained by differential centrifuging was checked by examining with the electron microscope. Samples were most commonly shadowed, but stained thin sections were also examined.

Hydrolysis of cell walls. I0-20 mg. dry wt of cell walls were hydrolysed with $2 \mathrm{~N}-\mathrm{H}_{2} \mathrm{SO}_{4}$ at $105^{\circ}$ for $3 \mathrm{hr}$. After cooling, the hydrolysate was neutralized with saturated $\mathrm{Ba}(\mathrm{OH})_{2}$ and solid $\mathrm{BaCO}_{3}$ and clarified by centrifugation and filtration.

Neutral sugars were estimated by gas chromatography of their alditol acetate derivatives (Sawardeker, Sloneker \& Jeanes, 1965), with mannose as an internal standard.

Amino sugar was estimated by the method of Levy \& McAllan (1959). Where an estimate of the relative contributions of glucosamine and muramic acid was required, the methods of Rondle \& Morgan (1955) and Cessi \& Piliego (I960) were used, the former method giving a different spectrum for these amino sugars, whilst the latter measures glucosamine only.

Protein was determined by the biuret method (Gornall, Bardawill \& David, 1957), with bovine plasma albumin as standard.

Reducing sugar was estimated by the method of Park \& Johnson (1949), phosphate by the method of Allen (1940), and nitrogen by the method of Folin \& Farmer (I912).

Ribosomal proteins were examined by polyacrylamide gel electrophoresis (Hurst, $1966 b)$.

Reagents. A.R. grade reagents were used as far as possible. Mannose was from T. G. Gurr Ltd., London, muramic acid from Sigma Chemical Co., St Louis, U.S.A., glucosamine from British Drug Houses Ltd., Poole, England, trypsin from Seravac Laboratories (Pty) Ltd., Maidenhead, England, RNA-ase from Koch-Light and Co. Ltd., Colnbrook, England and lysozyme from Armour Pharmaceutical Co., Eastbourne, England.

\section{RESULTS}

\section{Production of nisin by cultures of Streptococcus lactis}

Analysis of stationary phase cultures of Streptococcus lactis shows that some of the nisin produced is excreted into the culture fluid (medium nisin) and the remainder bound to the cocci (cell nisin; Hurst \& Dring, 1967). Table I shows the concentration and distribution of nisin in stationary phase cultures after growth with and without $\mathrm{pH}$ control. $S$. lactis is a vigorous acid producer and in an uncontrolled fermentation a limiting value of $\mathrm{pH}_{4.2}$ may be reached (acid culture); when the culture is maintained at $\mathrm{pH} 6.8$ (neutral culture) a higher yield of organism is obtained $(2.6 \mathrm{mg}$. dry wt/ml. as compared with $0.8 \mathrm{mg}$. dry $\mathrm{wt} / \mathrm{ml}$.). It can be seen that not all the nisin originally present (i.e. cells + medium) can be accounted for after separation of culture fluid from cells (i.e. medium nisin and cell nisin). In these experiments $7 \%$ of the nisin was cell bound in the acid culture and $61 \%$ in the neutral culture. The nisin content of cocci was not diminished by prolonged washing with water or $0 \cdot 01 \mathrm{M}$-sodium phosphate buffer (pH 6.8). 


\section{Chemical fractionation of Streptococcus lactis organisms}

Cocci from an acid stationary-phase culture were fractionated by the method of Park \& Hancock (1960) and the nisin content of the different fractions estimated; the results are shown in Table 2. Most of the nisin was recovered in the aqueous ethanolsoluble and trypsin-insoluble fractions. Only $72 \%$ of the nisin originally present in the whole cocci was recovered after this chemical fractionation. In one experiment the alcohol extraction step was repeated four times before passing on to the next extraction

Table I. Nisin yield and distribution in cultures of Streptococcus lactis grown with and without $\mathrm{pH}$ control

Samples from stationary phase cultures were assayed for nisin content directly (complete culture), and after separation of cocci from culture fluid by centrifugation. The nisin content of cocci was estimated after washing in fresh medium and resuspending and extracting with an equal volume of hot $0.05 \mathrm{~N}-\mathrm{HCl}$.

\begin{tabular}{|c|c|c|}
\hline & \multicolumn{2}{|c|}{ Nisin $(\mu \mathrm{g} . / \mathrm{ml}$. culture $)$} \\
\hline & $\begin{array}{l}\text { Without pH } \\
\text { control (ter- } \\
\text { minal } \\
\text { pH } 4 \cdot 2 \text { ) }\end{array}$ & $\begin{array}{l}\text { With pH } \\
\text { control (con- } \\
\text { trolled to } \\
\text { pH 6.8) }\end{array}$ \\
\hline Complete culture & 30 & I94 \\
\hline Culture fluid & 25 & 52 \\
\hline Cocci & 2 & 82 \\
\hline
\end{tabular}

Table 2. Distribution of nisin after a chemical fractionation of Streptococcus lactis organisms

Washed stationary-phase cocci (grown without $\mathrm{pH}$ control; 'acid' cocci) were fractionated by the method of Park \& Hancock (1960), and the distribution of nisin estimated by bioassay.

Nisin content
$(\%)$ of total
recovered

Cold trichloroacetic acid soluble I

Aqueous ethanol soluble $\quad 57$

Hot trichloroacetic acid soluble 3

Trypsin-soluble 2

Trypsin-insoluble residue $\quad 36$

with hot trichloracetic acid. In this case the first alcohol extraction still contained $57 \%$ of the nisin and the subsequent extractions contained negligible amounts. The repeated alcohol extractions did not affect the amount of nisin recovered from the trypsin-insoluble residue which remained $36 \%$ as shown in Table 2 . When whole cocci were incubated with trypsin ( $100 \mu \mathrm{g} . / \mathrm{ml}$. in $0.0 \mathrm{I} \mathrm{M}-\mathrm{NaHCO}_{3}$ at $37^{\circ}$ for $3 \mathrm{hr}$ ) there was no decrease in their nisin content.

\section{Physical fractionation of Streptococcus lactis organisms; nature of the fractions}

Broken cocci were fractionated by differential centrifugation as described. The $10,000 \mathrm{~g}$ pellet material was examined by electron microscopy and showed the classical appearance of cell walls (Salton, I964). With increasing purification the walls became thinner and less easy to see but even after extraction with hot formamide $\left(200^{\circ}\right.$ for I5 $\mathrm{min}$ ) they retained their original shape. 
The $30,000 \mathrm{~g}$ deposit was pale yellow and contained irregularly shaped particles, about one-tenth the size of cell walls. Chemical analysis supported the suggestion that the $30,000 \mathrm{~g}$ deposit was mostly membraneous material.

\section{Table 3. Distribution of nisin after physical fractionation of disrupted Streptococcus lactis organisms}

Cocci from stationary phase cultures ('acid' and 'neutral') were harvested, washed, disrupted and fractionated by differential centrifugation. The nisin content of the fractions was estimated by bioassay.

\begin{tabular}{|c|c|c|c|c|}
\hline \multirow[t]{2}{*}{ 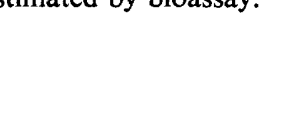 } & \multicolumn{4}{|c|}{ Distribution of nisin } \\
\hline & \multicolumn{2}{|c|}{ Acid culture } & \multicolumn{2}{|c|}{ Neutral culture } \\
\hline Fraction & $\%$ dry wt & $\begin{array}{l}\% \text { of total } \\
\text { recovered }\end{array}$ & $\%$ dry wt & $\begin{array}{l}\% \text { of total } \\
\text { recovered }\end{array}$ \\
\hline Whole cocci & 0.94 & 100 & $2 \cdot 63$ & 100 \\
\hline 10,000 $\mathrm{g}$ deposit & $\mathrm{r} \cdot 98$ & 65 & $2 \cdot 70$ & 43 \\
\hline $30,000 \mathrm{~g}$ deposit & $2 \cdot 10$ & 9 & $2 \cdot 47$ & 4 \\
\hline $100,000 \mathrm{~g}$ deposit & $x \cdot 66$ & 18 & $2 \cdot 42$ & 7 \\
\hline $\begin{array}{l}\text { Ioo,000 } \mathrm{g} \text { supernatant } \\
\text { fluid }\end{array}$ & 0.04 & 2 & 0.28 & 5 \\
\hline $\begin{array}{l}\text { Recovery }(\%) \text { of that } \\
\text { in unbroken cells }\end{array}$ & - & 94 & - & 59 \\
\hline
\end{tabular}

Table 4. Composition of Streptococcus lactis cell wall

Cell walls were prepared by differential centrifugation of disrupted 'acid' stationary phase cocci. Intact cocci were removed by discarding the $3000 \mathrm{~g}$ deposit. Cell walls were deposited at $10,000 \mathrm{~g}$, washed with $\mathrm{I} \mathrm{M}-\mathrm{NaCl}$, digested with trypsin and washed with water. Neutral sugars, amino sugars and reducing substances were estimated after hydrolysis of ro mg. of cell walls in $2 \mathrm{~N}-\mathrm{H}_{2} \mathrm{SO}_{4}$ for $3 \mathrm{hr}$ at $105^{\circ}$. Amino sugar is expressed as glucosamine equivalents and reducing substances as glucose equivalents. Protein was estimated by the biuret method, with bovine plasma albumin as standard.

$\begin{array}{lrlc} & \begin{array}{c}\% \text { dry wt of } \\ \text { cell wall }\end{array} & \begin{array}{c}\% \text { dry wt of } \\ \text { cell wall }\end{array} \\ \text { Amino sugar } & 9 \cdot 0 & \text { Phosphate } & 0.6 \\ \text { Rhamnose } & 20 \cdot 3 & \text { Nitrogen } & 7 \cdot 0 \\ \text { Glucose } & 5 \cdot 0 & \text { Protein } & 5 \cdot 0 \\ \text { Galactose } & 3 \cdot 3 & \text { Nisin } & 2 \cdot 2 \\ \text { Ribose } & \mathbf{I} \cdot 7 & \text { Ash } & 9 \cdot 5 \\ \text { Reducing substances } & 26 \cdot 2 & & \end{array}$

Analysis of the $100,000 \mathrm{~g}$ deposit indicated that it was mostly ribosomes (6I \% RNA, $39 \%$ protein). Polyacrylamide gel electrophoresis of basic proteins from these ribosomes revealed about 20 distinct bands (see Traut, I966; Moller \& Castleman, 1967) including a band with the same mobility as nisin marker; the presence of nisin was confirmed by bioassay.

\section{Distribution of nisin in physically separated fractions of broken organisms}

Acid-grown and neutral-grown cocci were disrupted, fractionated by differential centrifugation and the nisin estimated in the various fractions; the results are given in Table 3.

Gravimetric determinations indicated that the cell wall contributed $30-40 \%$ of 
the dry wt of whole organisms, membranes $4 \%$, ribosomes $10 \%$, and supernatant fluid fraction (cell-sap) 46-56\%. Complete recovery of fractions was not usually attempted. Although in the experiment quoted the yield of nisin was only threefold higher in the 'neutral' cocci, the results for 'acid' cocci were variable and on occasion they contained very little nisin (e.g. total nisin only $5 \mu \mathrm{g} . / \mathrm{ml}$. medium).

\section{Analysis of cell walls}

Table 4 summarizes the results for the composition of cell walls prepared from 'acid' stationary-phase cocci. The purification of cell walls involves a trypsin digestion (see Methods) and during this procedure the protein content decreased from $45 \%$ of the

\section{Table 5. Contribution of cell walls to dry weight of whole Streptococcus lactis organisms}

Cell walls were prepared from exponential ( $3 \mathrm{hr}$ growth) and stationary phase (overnight growth) as described for Table 4. The amino sugar (as glucosamine equivalents) and rhamnose content of whole organisms and cell walls was estimated after hydrolysis in $2 \mathrm{~N}-\mathrm{H}_{2} \mathrm{SO}_{4}$ for $3 \mathrm{hr}$ at $105^{\circ}$. Calculation of the cell wall's contribution to the dry weight of the whole cocci is based on the assumption that rhamnose and amino sugars occur exclusively in the cell wall (this is supported by analysis of the other fractions).

\begin{tabular}{|c|c|c|c|c|}
\hline & & & $\begin{array}{r}\text { Cell wall } \\
\text { of }\end{array}$ & $\begin{array}{l}\% \text { dry wt } \\
\text { occi }\end{array}$ \\
\hline & $\begin{array}{l}\text { Rhamnose } \\
\text { (\% dry wt) }\end{array}$ & $\begin{array}{l}\text { Amino } \\
\text { sugar } \\
\text { (\% dry wt) }\end{array}$ & $\begin{array}{c}\text { By Rham- } \\
\text { nose }\end{array}$ & $\begin{array}{l}\text { By amino } \\
\text { sugar }\end{array}$ \\
\hline Exponential cocci & $7 \cdot 9$ & $2 \cdot 8$ & $29 \cdot 2$ & $3 I \cdot 2$ \\
\hline 'Exponential' walls & $27 \cdot 0$ & $9 \cdot 0$ & & \\
\hline Acid stationary cocci & $6 \cdot 8$ & $2 \cdot 6$ & $29 \cdot 6$ & $3 I \cdot 6$ \\
\hline 'Acid stationary' walls & $23 \cdot 0$ & $8 \cdot 2$ & & \\
\hline Neutral stationary cocci & $8 \cdot 4$ & $3 \cdot 7$ & $41 \cdot 5$ & $42 \cdot 0$ \\
\hline 'Neutral stationary' walls & $20 \cdot 3$ & $9 \cdot 3$ & & \\
\hline
\end{tabular}

Table 6. Comparison of formamide-soluble fraction and formamide-insoluble fraction from cell wall of Streptococcus lactis

Cell walls were prepared from 'acid' stationary phase cocci as described for Table 4 and heated in formamide at $200^{\circ}$ for $15 \mathrm{~min}$. The resultant formamide-insoluble fraction was deposited by centrifuging at $30,000 \mathrm{~g}$ for $\mathrm{I} 5 \mathrm{~min}$, and washed twice with water. Rhamnose and amino sugar (as glucosamine equivalents) were estimated after hydrolysis of the forma-

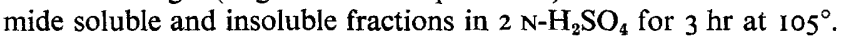

\begin{tabular}{lcccc} 
& \multicolumn{4}{c}{ Mole ratios } \\
\cline { 2 - 2 } & Rhamnose & Glucose & Galactose \\
Formamide-soluble & $\mathrm{I} \cdot \mathrm{I}$ & $5 \cdot 2$ & $\mathrm{I} \cdot \mathrm{O}$ & $0 \cdot 8$ \\
Formamide-insoluble & $\mathrm{I} \cdot \mathrm{O}$ & $0 \cdot \mathrm{I}$ & $0 \cdot \mathrm{I}$ & $0 \cdot \mathbf{I}$
\end{tabular}

dry wt of the walls to $5 \%$. The nitrogen content suggested that the protein content of purified walls was somewhat higher. However, it should be remembered that the protein was expressed as bovine serum albumin and this might be the reason for the discrepancy. Nisin was not lost from walls during the trypsin digestion. Attempts to demonstrate the presence of teichoic acid in the walls proved negative, the phosphate content being unchanged after prolonged extraction with trichloroacetic acid $(5 \%$ trichloroacetic acid at $0^{\circ}$ for $72 \mathrm{hr}$ ). A comparison of the rhamnose and amino sugar 
contents of whole organisms and of cell walls permitted an estimate of the contribution of walls to the dry wt of whole cocci (such a calculation assumes that these carbohydrates occur exclusively in the wall). Figures are given in Table 5 for exponential and stationary-phase organisms.

\section{Formamide extraction of walls}

Previous work with group A streptococci (Krause \& McCarty, I96I) showed that Fuller's (1938) formamide extraction was an efficient means of separating polysaccharide from mucopeptide. Extraction of Streptococcus lactis cell walls with formamide at $200^{\circ}$ for $15 \mathrm{~min}$. yielded two fractions: formamide-soluble and formamideinsoluble. During the extraction procedure there was a dramatic decrease in turbidity. The ratio of amino sugar to rhamnose, glucose and galactose in acid hydrolysates of the formamide-soluble and formamide-insoluble fractions was markedly different (see Table 6). The $E$ 505/530 $\mathrm{m} \mu$ ratios in the Rondle \& Morgan (1955) estimation for amino sugar in the two fractions were 0.88 for the formamide-soluble fraction and $\mathrm{I} \cdot 35$ for the formamide-insoluble fraction; in the same assay glucosamine alone gave a ratio of 0.85 whilst an equimolar mixture of muramic acid and glucosamine gave $I \cdot 33$.

\section{Sensitivity to lysozyme}

Whole organisms of Streptococcus lactis and cell walls were incubated with lysozyme ( IOO $\mu \mathrm{g} . / \mathrm{ml}$. in $0 . \mathrm{I} \mathrm{M}$-sodium phosphate buffer $\mathrm{pH} 7.0$ at $37^{\circ}$ ) and the extinction at $700 \mathrm{~m} \mu$ followed. There was a very slow decrease in both cases (about $50 \%$ in $24 \mathrm{hr}$ ). Extraction of cell walls with formamide $\left(200^{\circ}\right.$ for $15 \mathrm{~min}$ ) or hot $10 \%$ trichloroacetic acid $\left(6 \mathrm{hr}\right.$ at $\left.60^{\circ}\right)$ caused a slight increase in sensitivity to lysozyme (see Schleifer \& Kandler, I 967 , who solubilized $S$. cremoris by this treatment).

\section{DISCUSSION}

Nisin is a strongly basic surface-active molecule (Hirsch, 1954) so that its distribution within the producer organism cannot easily be established. For this reason two different methods of analysis of the Streptococcus lactis organisms were used here: chemical and physical. In the chemical separation $57 \%$ of the nisin was recovered in the fraction soluble in aqueous ethanol. This fraction presumably contained most of the membrane material and also any ethanol-soluble protein present elsewhere in the cocci. Centrifugally prepared membranes contained less nisin than the aqueous ethanol soluble fraction ( $9 \%$ of total as compared with $57 \%$ of total). Thus much of the nisin in the alcohol soluble fraction did not come from membranes. However, in both fractionation procedures a comparable amount of nisin was found associated with the wall material (trypsin-insoluble residue and $10,000 \mathrm{~g}$ deposit). The higher nisin content of neutrally-grown cocci was partly due to the increased amount of wall material present and to the higher nisin content of the walls (Tables 3, 5). Although free nisin is ethanol soluble, nisin attached to the trypsin-insoluble residue was not removed by repeated extraction with ethanol or by repeated washing with $\mathrm{M}-\mathrm{NaCl}$. The nature of the bond between wall material and nisin remains to be determined. In its association with cell wall, stability to boiling with acid and solubility in ethanol, nisin resembles the M protein of the group A Streptococci (Krause \& McCarty, 196I). Physical fractionation of neutrally-grown $S$. lactis organisms gave a poorer recovery of nisin than did acid- 
grown cocci; more of the nisin in neutrally grown cocci may have been loosely bound and lost during washing. However, some of the extra nisin in the neutral cocci was found in the cell sap (Table 3). Differences in the concentration of nisin inside and outside the cocci may be caused by different $\mathrm{pH}$ values. During growth without $\mathrm{pH}$ control the lactic acid produced by fermentation may be causing an acid extraction of the 'acid' cocci. However, in a culture maintained at neutral $\mathrm{pH}$, the inside of the cocci might be at a more acid $\mathrm{pH}$ value than that of the medium. Since nisin is more soluble at acid $\mathrm{pH}$ values it may distribute itself accordingly. Zarlengo \& Abrams (1964) reported that the intracellular $\mathrm{pH}$ value of stationary-phase $S$. faecalis might be as low as $\mathrm{pH} 5 \cdot 0$.

The cell wall of Streptococcus lactis contains mucopeptide and a polysaccharide which can be separated by formamide extraction. However, even after $15 \mathrm{~min}$. in boiling formamide, rhamnose was still present in the mucopeptide (insoluble residue). Residual rhamnose probably means incomplete removal of polysaccharide, and this may have caused the poor sensitivity to lysozyme. Although Krause \& McCarty (I96I) were unable to extract all the rhamnose from group A streptococcal cell walls with formamide, the mucopeptide obtained was completely solubilized by lysozyme. Table 6 suggests that the formamide-soluble polysaccharide of $S$. lactis contains rhamnose, glucose, galactose and glucosamine in the molar ratio of $5: \mathrm{I}: \mathrm{I}: \mathrm{I}$, the glucosamine in the polysaccharide being presumably $N$-acetylated, since partial acid-hydrolysates contained $N$-acetylamino sugar. Polysaccharide contributed about $30 \%$ of the dry wt of the $S$. lactis wall and mucopeptide about 10\%. Schleifer \& Kandler (I967) established the composition and amino acid sequence of mucopeptide from $S$. lactis. Little data is available about the ash content of cell walls but the value found here for $S$. lactis (about $10 \%$ ) is similar to that quoted by Holdsworth (1952) for Corynebacterium diphtheria. Ribose was always present in the purified wall preparations of S. lactis, even after treatment with RNA-ase; the wall, membrane and other associated organelles may form a highly integrated structure in this organism.

We thank Dr R. Young for advice on chromatography, Mr M. Pugh for technical assistance and Mr M. Stubbs for electron microscopy.

\section{REFERENCES}

Allen, R. J. L. (1940). The estimation of phosphorus. Biochem. J. 34, 858 .

Butler, J. A. V. \& ChIPPERfield, A. R. (1967). Inhibition of RNA polymerase by histones. Nature, Lond. 215, 1 I 88.

Cessi, C. \& Piliego, F. (I960). The determination of amino sugars in the presence of amino acid and glucose. Biochem. J. 77, 508.

Cheeseman, G. C. \& BerRidge, N. J. (1959). Observations on the molecular weight and chemical composition of nisin A. Biochem. J. 7r, I85.

De Reuck, A. V. S. \& Knight, J. (eds.) (1966). Histones. Ciba Foundation Study Group, no. 24. London: J. and A. Churchill.

Folin, O. \& FARMER, C. J. (I912). A new method for the determination of total nitrogen in urine. J. biol. Chem. II, 493 .

Fuller, A. T. (1938). The formamide method for the extraction of polysaccharides from haemolytic streptococci. Br. J. Exp. Path. 19, I30.

Gornall, A. G., Bardawill, C. S. \& David, M. M. (1957). Biuret method. Meth. Enzymol. 3, 450.

Gross, E. \& MORELL, J. L. (1967). The presence of dehydroalanine in the antibiotic nisin and its relationship to activity. J. Am. chem. Soc. 89, 279I. 
HaLVORSON, H. O. (1965). Sequential expression of biochemical events during intracellular differentiation. Symp. Soc. gen. Microbiol. 15, 343.

HolDsworth, E. S. (1952). The nature of cell wall of Corynebacterium diphtheria. Isolation of an oligosaccharide. Biochim. biophys. Acta 9, 19.

HiRsCH, A. (1954). Some polypeptide antibiotics. J. appl. Bact. 17, 108.

HURST, A. (1966a). Biosynthesis of the antibiotic nisin by whole Streptococcus lactis organisms. J. gen. Microbiol. 44, 209.

HuRST, A. (1966 b). Biosynthesis of the antibiotic nisin and other basic peptides by Streptococcus lactis grown in batch culture. J. gen. Microbiol. 45, 503.

HuRst, A. (1967). Function of nisin and nisin-like basic proteins in the growth cycle of Streptococcus lactis. Nature, Lond. 214, 1232.

HURST, A. \& DRING, G. J. (I967). The relation of the length of lag-phase of growth to the synthesis of nisin and other basic proteins by Streptococcus lactis grown under different cultural conditions. J. gen. Microbiol. 50, 383.

Ingram, L., Tombs, M. P. \& Hurst, A. (1967). Mobility-molecular weight relationships of small proteins and peptides in acrylamide gel electrophoresis. Analyt. Biochem. 20, 24.

KraUSE, R. M. \& MCCARTY, M. (196I). Studies on the chemical structure of the streptococcal cell wall. I. The identification of a mucopeptide in the cell walls of groups $A$ and $A$ variant streptococci. J. exp. Med. II4, I27.

Levy, G. A. \& MCAllan, A. (1959). The $N$-acetylation and estimation of hexosamines. Biochem.J. $73,127$.

MAtTICK, A. T. R. \& HiRSCH, A. (I947). Further observations on an inhibitory substance (nisin) from lactic streptococci. Lancet ii, 5 .

Moller, W. \& Castleman, H. (1967). Primary structure heterogeneity in ribosomal proteins from Escherichia coli. Nature, Lond. 215, 1293.

MunRo, A. J., JACKson, R. J. \& KoRner, A. (1964). Studies on the nature of polysomes. Biochem. J. 92, 289.

PARK, J. T. \& HANCOCK, R. (I960). A fractionation procedure for studies of the synthesis of cell wall mucopeptide and of other polymers in cells of Staphylococcus aureus. J. gen. Microbiol. 22, 249.

Park, J. T. \& Johnson, M. J. (1949). A sub-microdetermination of glucose. J. biol. Chem. 181, I 49.

Paulus, H. (1967). Polymixins. In Antibiotics. Ed. by D. Gottlieb and P. D. Shaw. Vol. 2, p. 254. New York: Springer-Verlag.

RoNDle, C. J. M. \& MORGAN, W. T. J. (1955). The determination of glucosamine and galactosamine. Biochem. J. 61, 586.

Salton, M. R. J. (1964). The Bacterial Cell Wall. Amsterdam: Elsevier Publ. Co.

Sawardeker, J. S., Sloneker, J. H. \& JeANeS, A. (1965). Quantitative determination of monosaccharides as their alditol acetates by gas liquid chromatography. Analyt. Chem. 37, 1602.

Schaeffer, P., Ionesco, H., Ryter, A. \& Balasa, G. (1963). La sporulation de Bacillus subtilis: étude génétique et physiologique. In Mécanismes de Régulation des Activités Cellulaires chez les Microorganisms, p. 553. Paris: Centre Natl. Rech. Scientifique.

SCHLEIFER, K. H. \& KANDLER, O. (I967). Zur chemischen Zusammensetzung der Zellewand der Streptokokken. II. Die Aminosäure - Sequenz des Mureins von Streptococcus lactis und $S$. cremoris. Arch. Mikrobiol. 57, 367.

TRAUT, R. R. (1966). Acrylamide gel electrophoresis of radioactive ribosomal protein. J. molec. Biol. 2I, 57 I.

Zarlengo, M. H. \& ABrams, A. (1963). Selective penetration of ammonia and alkylamines into Streptococcus faecalis and their effect on glycolysis. Biochim. biophys. Acta 71, 65 . 